\title{
FAKTOR PENENTU TINGKAT PEMAHAMAN AKUNTANSI
}

\author{
Komang Krishna Yogantara ${ }^{1}$ \\ Fakultas Bisnis Universitas Triatma Mulya-Bali ${ }^{1}$ \\ email: krishna.yogantara@triatmamulya.ac.id
}

\begin{abstract}
This study aims to examine the effect of lectures while working, learning behavior and emotional intelligence on the level of understanding of regular afternoon accounting students of accounting study programs at Triatma Mulya University. The dependent variable in this research is accounting understanding $(Y)$. While the independent variables in this study are lectures while working (X1), learning behavior (X2) and emotional intelligence (X3). The population in this study were all regular evening students of the 2016-2019 accounting study program who are still active at Triatma Mulya University. The sample in this study was selected by purposive sampling method and obtained a sample of 96 students. The research method used is quantitative research and for data analysis using multiple regression analysis. The results of the study stated that lecture while working had a positive effect on accounting understanding, seen from the X1 significance value of 0,000. The positive influence between lectures while working with the level of understanding of accounting identifies that students who are active in carrying out two activities at once, namely lecturing and working together and supporting each other. Furthermore, learning behavior has a positive effect on accounting understanding, seen from the X2 significance value of 0,000. This indicates that the better the student's learning behavior, the better the level of understanding of the student's accounting. While emotional intelligence also has a positive effect on accounting understanding, it can be seen from the X3 significance value of 0.002. This emotional intelligence shows that someone who is able to control his emotional intelligence well, then understanding accounting will also increase.
\end{abstract}

Keywords: $\quad$ lecture, behavior, intelligence, accounting understanding.

\section{PENDAHULUAN}

Pendidikan merupakan hal yang sangat penting di masa sekarang ini. Pendidikan merupakan salah satu faktor yang menentukan kemajuan suatu bangsa. Maka tidak heran lagi semua orang menginginkan pendidikan yang tinggi untuk masa depan mereka kedepannya. Persaingan dunia kerja saat ini semakin tajam akibat adanya globalisasi. Untuk itu banyak orang memutuskan untuk bekerja sembari melanjutkan pendidikan mereka dengan harapan mendapatkan pekerjaan yang lebih baik lagi dari sebelumnya sesuai dengan pendidikan yang ditempuh. Pendidikan tinggi akuntansi yang menghasilkan lulusan dalam bidang akuntansi saat ini dituntut untuk tidak hanya menghasilkan lulusan yang menguasai kemampuan di bidang akademik, tetapi juga mempunyai kemampuan yang bersifat teknis analisis dalam bidang humanistic skill dan professional skill sehingga mempunyai nilai tambah dalam bersaing di dunia kerja (Budhiyanto dan Nugroho, 2004: 260). 
Kuliah sembari bekerja bukanlah hal yang baru di era sekarang ini, dulu umumnya mahasiswa yang kuliah sembari bekerja ialah mahasiswa yang berasal dari golongan miskin. Namun saat ini banyak hal yang melatarbelakangi minat mahasiswa untuk bekerja sembari kuliah yaitu salah satunya ialah untuk memenuhi kebutuhan mereka selama kuliah ada juga yang karna hobi mereka adalah pekerjaan yang mereka jalani.

Penelitian mengenai tingkat pemahaman akuntansi telah banyak dilakukan, namun terdapat ketidakkonsistenan atas hasil penelitian pada variabel perilaku belajar dan kecerdasan emosional. Hasil penelitian terdahulu juga menjelaskan untuk variabel perilaku belajar berpengaruh positif dan signifikan terhadap tingkat pemahaman akuntansi oleh Diabnita (2014). Penelitian menurut Sari \& Sartika (2018) perilaku belajar berpengaruh terhadap tingkat pemahaman akuntansi. Hasil penelitian yang berbeda oleh Rohmah (2019) menunjukkan bahwa perilaku belajar tidak berpengaruh terhadap pemahaman akuntansi.

$$
\text { Variabel kecerdasan }
$$

emosional dalan penelitian ini masih diketahui adanya inkonsistensi hasil penelitian-penelitian terdahulu diantaranya penelitian oleh Santoso \& Rinaldi (2018) variabel kecerdasan emosional secara parsial tidak berpengaruh signifikan terhadap pemahaman akuntansi. Sedangkan penelitian yang dilakukan oleh Diabnita (2014) memperoleh hasil bahwa kecerdasan emosional berpengaruh positif dan signifikan terhadap tingkat pemahaman akuntansi.
Pemilihan Universitas Triatma Mulya khususnya mahasiswa regular sore program studi akuntansi sebagai objek penelitian. Universitas Triatma Mulya merupakan lembaga pendidikan tinggi swasta yang telah terakreditasi B, serta dipandang memiliki potensi besar untuk mencetak tenaga profesional dibidang akuntansi sesuai visi, misi dan tujuan. Untuk itu semua lulusan dari Universitas Triatma Mulya baik dari kelas pagi ataupun sore program studi akuntansi sudah seharusnya memiliki tingkat pemahaman akuntansi yang baik setelah menempuh pendidikan akuntansi.

\section{TINJAUAN PUSTAKA Pemahaman Akuntansi}

Menurut Suwardjono (2005:4) pengetahuan akuntansi dapat dipandang dari dua sisi pengertian yaitu sebagai pengetahuan profesi (keahlian) yang dipraktekkan di dunia nyata dan sekaligus sebagai suatu disiplin pengetahuan yang diajarkan diperguruan tinggi. Akuntansi sebagai objek pengetahuan diperguruan tinggi, akademisi memandang akuntansi sebagai dua bidang kajian yaitu bidang praktek dan teori. Teori akuntansi tidak lepas dari praktik akuntansi karena tujuan utamanya adalah menjelaskan praktik akuntansi berjalan dan memberikan dasar bagi pengembangan praktik. Akuntansi cenderung dikembangkan atas dasar pertimbangan nilai (value judgment), yang dipenuhi oleh faktor lingkungan tempat akuntansi dipraktikkan. Dalam hal ini, pemahaman akuntansi setiap mahasiswa dapat dilihat dari nilai mata kuliah akuntansi yang ditempuh selama awal pembelajaran hingga tahap ujian memproleh nilai diatas nilai $C$ atau minimal mendapat nilai $B$. 


\section{Kuliah Sambil Bekerja}

Mahasiswa yang bekerja adalah mahasiswa yang aktif dalam menjalankan dua ativitas sekaligus yaitu kuliah dan bekerja. Kedua aktivitas tersebut dapat dilakukan secara bersamaan dan saling mendukung satu sama lain. Dengan bekerja, mahaiswa dapat mengumpulkan uang untuk keperluan kuliahnya sementara dengan kuliah seseorang dapat memperoleh ilmu yang lebih di pendidikan tingginya dan bisa di aplikasikan di pekerjaanya. Masa sekarang adalah masa yang penuh dengan persaingan diberbagai aspek dan bidang kehidupan, termasuk didalamnya bidang pekerjaan. Tidak terkecuali negara Indonesia yang memiliki jumlah penduduk yang besar sedangkan lapangan pekerjaan yang tersedia tidak sebanding dengan jumlah tenaga kerja. Hal tersebut membuat persaingan untuk mendapatkan pekerjaan menjadi sangat ketat.

\section{Perilaku Belajar}

Menurut Soemanto (2012:6) perilaku belajar adalah suatu sikap yang muncul dari diri mahasiswa dalam menanggapi dan meresponi setiap kegiatan belajar mengajar yang terjadi, menunjukkan sikapnya apakah antusias dan bertanggung jawab atas kesempatan belajar yang diberikan kepadanya. Perilaku belajar memiliki dua penilaian kualitatif yakni baik dan buruk tergantung kepada individu yang mengalaminya, untuk meresponinya dengan baik atau bahkan acuh tak acuh.

\section{Kecerdasan Emosional}

Kecerdasan emosional menurut Goleman (2003:45) adalah kemampuan mengendalikan perasaan kita sendiri dan perasaan orang lain, kemampuan memotivasi dari sendiri dan kemampuan mengelola emosi dengan baik pada diri sendiri dan dalam kemampuan mengelola emosi dengan baik pada diri sendiri dan dalam hubungan dengan orang lain.

\section{METODE PENELITIAN Desain Penelitian}

Tipe penelitian ini menggunakan jenis penelitian kuantitatif. Penelitian kuantitaif digunakan untuk menguji hipotesis, yang bertujuan untuk mengetahui apakah terdapat pengaruh antara kuliah sambil kerja, perilaku belajar dan kecerdasan emosional terhadap tingkat pemahaman akuntansi pada mahasiswa reguler sore program studi akuntansi di Universitas Triatma Mulya. Penelitian ini menggunakan skala likert pada alat ukur kuliah sambil kerja, perilaku belajar, kecerdasan emosional dan pemahaman akuntansi.

\section{Populasi dan Sampel}

Populasi dalam penelitian ini adalah seluruh mahasiswa regular sore program studi akuntansi yang masih aktif sampai tahun ajaran 2019/2020 Fakultas Bisnis di Universitas Triatma Mulya yaitu sejumlah 112 mahasiswa. Sampel dalam penelitian ini dipilih dengan menggunakan metode purposive sampling yang bertujuan untuk mendapatkan sampel sesuai dengan kriteria yang ditentukan. Purposive sampling yaitu tipe pemilihan sampel secara tidak acak berdasarkan pertimbangan tertentu yang ditentukan dengan tujuan atau permasalahan dalam penelitian (Indriantoro dan Supomo, 1999: 131). Kriteria penelitian adalah mahasiswa regular sore prodi 
akuntansi angkatan 2016, 2017 dan 2018. Hal ini karena mahasiswa angkatan tersebut telah menempuh pendidikan lebih lama dan tentunya memiliki pemahaman akuntansi yang cukup. Jumlah sampel yang di dapatkan berdasarkan kreteria yaitu sebanyak 96 mahasiswa regular sore program studi akuntansi di Universitas Triatma Mulya.

\section{Teknik Pengumpulan Data}

Teknik yang diambil dalam pengumpulan data yaitu kuesioner. Metode ini dilakukan dengan mendatangi langsung responden, memberikan atau menyebarkan daftar pertanyaan dan pernyataan kepada responden yaitu mahasiswa reguler sore program studi akuntansi di Universitas Triatma Mulya angkatan tahun 2016, 2017 dan 2018.

\section{Teknik Analisis Data}

Peneliti menggunakan model regresi linear berganda dengan program Statistical Package for Social Science (SPSS) 25.0.

\section{HASIL DAN PEMBAHASAN \\ Hasil Uji Instrumen \\ Uji Validitas}

Hasil uji validitas menunjukan bahwa seluruh item-item pernyataan dan pertanyaan memiliki nilai koefisien korelasi yang lebih besar dari 0,30 seluruh indikator pernyataan dan pertanyaan tersebut telah memenuhi syarat validitas data.

\section{Uji Reliabilitas}

Hasil uji reliabilitas menunjukan bahwa nilai cronbach's alpha untuk masing-masing variabel penelitian menunjukan nilai $>0,6$.

\section{Hasil Uji Asumsi Klasik Uji Normalitas}

Berdasarkan hasil uji nilai Asymp. Sig. (2-tailed) berada diatas 0,05 sehingga dapat disimpulkan bahwa data yang digunakan dalam penelitian ini berdistribusi normal.

\section{Uji Multikolinearitas}

Berdasarkan hasil uji menunjukkan bahwa ketiga variabel memiliki nilai Tolerance lebih besar dari 0,10 dan nilai VIF lebih kecil dari 10. Dengan demikian dapat disimpulkan bahwa seluruh variabel bebas dalam penelitian ini tidak terjadi multikolinearitas.

\section{Uji Heteroskedastitas}

Hasil uji menunjukkan bahwa nilai signifikansi pada semua variabel independen lebih besar dari 0,05. Disimpulkan bahwa semua variabel independen tidak terjadi heterokedastisitas.

\section{Analisis Regresi Berganda}

Pengujian regresi linear berganda berguna untuk mengetahui pengaruh variabel independen (kuliah sambil bekerja, prilaku belajar dan kecerdasan emosional) terhadap variabel dependen (pemahaman akuntansi). Berdasarkan pengujian diperoleh hasil yang dapat disajikan dalam tabel berikut. 


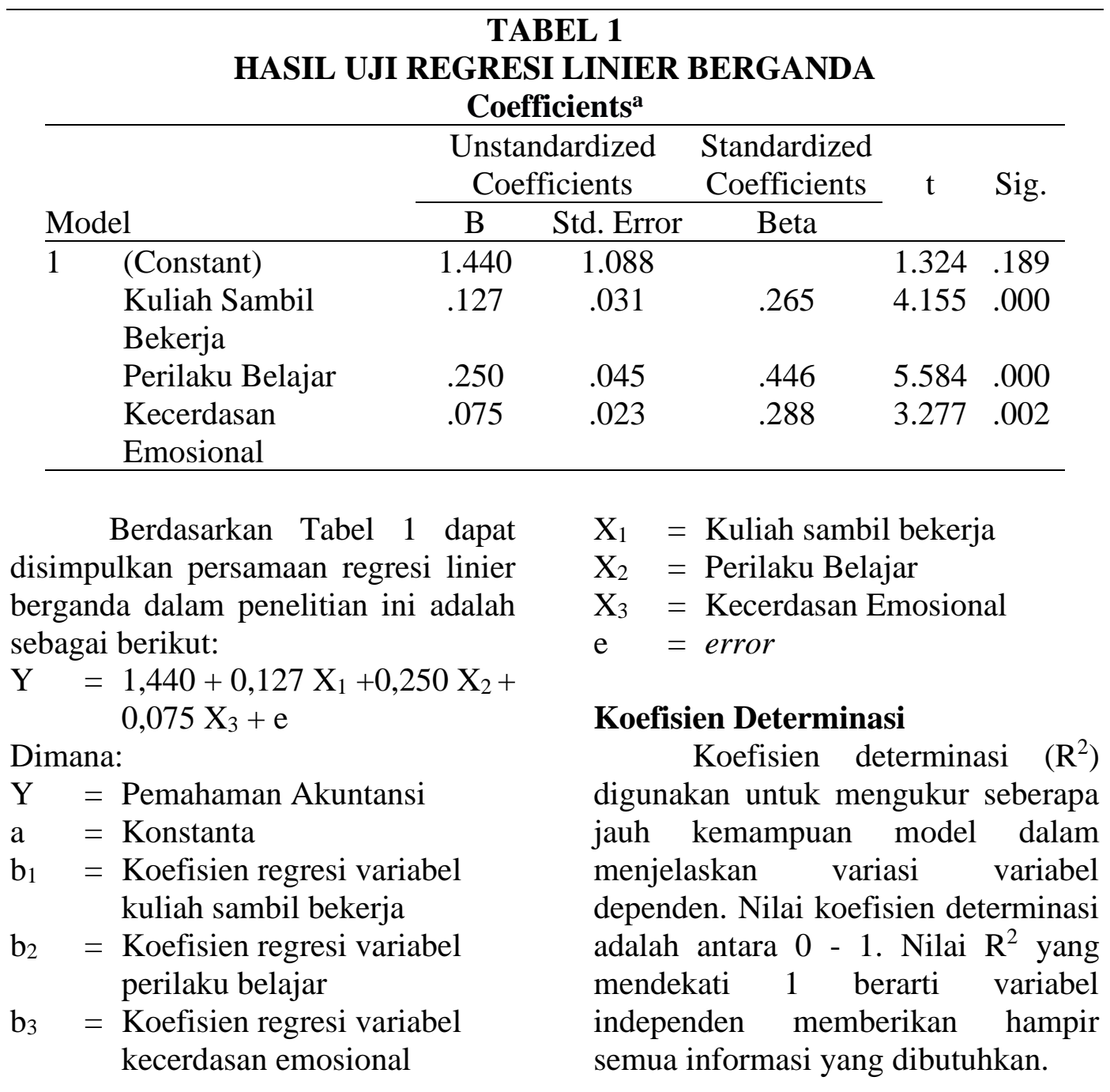

TABEL 2

HASIL KEOFISIEN DETERMINASI Model Summary

\begin{tabular}{lcccc}
\hline Model & R & R Square & $\begin{array}{c}\text { Adjusted R } \\
\text { Square }\end{array}$ & $\begin{array}{c}\text { Std. Error of the } \\
\text { Estimate }\end{array}$ \\
\hline 1 & $.927^{\mathrm{a}}$ & .859 & .854 & 1.398 \\
\hline a. Predictors: (Constant), Kecerdasan Emosional, Kuliah Sambil Bekerja, \\
Perilaku Belajar
\end{tabular}

Pengaruh Kuliah Sambil Bekerja Terhadap Tingkat Pemahaman Akuntansi

Hasil pengujian menunjukan bahwa variabel kuliah sambil bekerja $\left(\mathrm{X}_{1}\right)$ berpengaruh positif terhadap tingkat pemahaman akuntansi (Y). Adanya pengaruh positif antara kuliah sambil bekerja dengan tingkat pemahaman akuntansi ini mengidentifikasikan bahwa mahasiswa yang aktif dalam menjalankan dua ativitas sekaligus yaitu kuliah dan bekerja secara bersamaan dan saling mendukung satu sama lain. Dengan bekerja, mahasiswa dapat mengumpulkan uang untuk keperluan kuliahnya sementara 
dengan kuliah seseorang dapat memperoleh ilmu lebih yang bisa di aplikasikan di pekerjaanya. Hasil penelitian ini didukung oleh penelitian yang dilakukan sebelumnya, yakni oleh Manurung \& Hamidi (2017) bahwa status bekerja mempunyai pengaruh positif dan signifikan terhadap pemahaman akuntansi.

\section{Pengaruh Perilaku Belajar Bekerja Terhadap Tingkat Pemahaman Akuntansi}

Hasil penelitian menunjukan bahwa perilaku belajar $\left(\mathrm{X}_{2}\right)$ berpengaruh positif terhadap tingkat pemahaman akuntansi (Y). Adanya pengaruh positif antara perilaku belajar dan tingkat pemahaman akuntansi ini mengindikasikan bahwa semakin baik perilaku belajar mahasiswa maka akan semakin baik juga tingkat pemahaman akuntansi mahasiswa tersebut. Artinya agar mahasiswa memiliki tingkat pemahaman akuntansi yang baik maka mahasiswa harus menigkatkan pula perilaku belajar mereka ke arah yang lebih baik seperti menambah jam belajar, belajar kelompok bersama teman-teman, disiplin dalam mengikuti pelajaran di kampus, luangkan waktu untuk mengulangngulang kembali pelajaran sehingga akan meningkatkan kemampuan mahasiswa tersebut dalam memahami akuntansi. Pandangan di atas sejalan dengan teori Soemanto (2012:6) perilaku belajar adalah suatu sikap yang muncul dari diri siswa dalam menanggapi dan meresponi setiap kegiatan belajar mengajar yang terjadi, menunjukkan sikapnya apakah antusias dan bertanggung jawab atas kesempatan belajar yang diberikan kepadanya. Hasil penelitian ini didukung oleh penelitian yang dilakukan sebelumnya, yakni oleh Sari \& Sartika (2018) membuktikan bahwa perilaku belajar berpengaruh positif terhadap tingkat pemahaman akuntansi. Namun hasil penelitian ini bertolak belakang dengan hasil penelitian oleh Rohmah (2019) menunjukkan bahwa perilaku belajar tidak berpengaruh terhadap pemahaman akuntansi

\section{Pengaruh Kecerdasan Emosional Terhadap Tingkat Pemahaman Akuntansi}

Hasil penelitian ini menunjukan bahwa kecerdasan emosional $\left(\mathrm{X}_{3}\right)$ berpengaruh positif pada tingkat pemahaman akuntansi (Y). Pemahaman akuntansi pada mahasiswa regular sore Universitas Triatma Mulya dipengaruhi oleh kecerdasan emosional ini menunjukkan bahwa seseorang yang mampu mengendalikan kecerdasan emosionalnya dengan baik, maka pemahaman akuntansi juga akan meningkat. Kemampuan mahasiswa dalam mengelola perasaannya, memotivasi diri sendiri, mampu berempati dan bekerja sama dengan orang lain dapat mendukung mahasiswa dalam pemahaman akuntansi. Pandangan di atas sejalan dengan teori pemahaman Bloom (1956) dengan ranah afektif, dimana dalam memahami sesuatu terutama berkaitan dengan akuntansi diperlukan sesuatu yang berhubungan dengan halhal yang bersifat emosional, seperti perasaan, motivasi, sikap, dan lain sebagainya (Yaumi, 2013). Penelitian ini sejalan dengan penelitian Saputra (2018), yang menunjukan hasil bahwa kecerdasan emosional berpengaruh positif terhadap Tingkat Pemahaman Akuntansi. Sari \& Sartika (2018) mengatakan bahwa kecerdasan 
emosional berpengaruh terhadap tingkat pemahaman akuntansi. Dapat diartikan bahwa semakin baik kecerdasan emosional seseorang, maka tingkat pemahaman akuntansinya juga akan semakin baik. Namun hasil penelitian ini bertolak belakang dengan hasil penelitian oleh Santoso \& Rinaldi (2018) menyatakan bahwa variabel kecerdasan emosional secara parsial tidak berpengaruh signifikan terhadap pemahaman akuntansi.

\section{SIMPULAN DAN SARAN Simpulan}

Simpulan yang didapat adanya pengaruh positif antara kuliah sambil bekerja dengan tingkat pemahaman akuntansi ini mengidentifikasikan bahwa mahasiswa yang aktif dalam menjalankan dua aktivitas sekaligus yaitu kuliah dan bekerja secara bersamaan dan saling mendukung satu sama lain.

Perilaku belajar dalam penelitian ini juga berpengaruh positif terhadap tingkat pemahaman akuntansi. Ini mengindikasikan bahwa semakin baik perilaku belajar mahasiswa maka akan semakin baik juga tingkat pemahaman akuntansi mahasiswa tersebut.

Kecerdasan emosional dalam penelitian ini juga berpengaruh positif terhadap tingkat pemahaman akuntansi. Ini menunjukkan bahwa seseorang yang mampu mengendalikan kecerdasan emosionalnya dengan baik, maka pemahaman akuntansi juga akan meningkat.
Saran

Saran yang dapat disampaikan adalah sebagai berikut:

1. Penelitian selanjutnya disarankan agar menambah jumlah responden dari berbagai mahasiswa regular sore prodi Akuntansi yang ada di beberapa Perguruan Tingggi yang ada di Bali sehingga dapat diketahui apakah kuliah sambil bekerja, perilaku belajar dan kecerdasan emosional benarbenar berpengaruh terhadap tingkat pemahaman akuntansi bagi mahasiswa regular sore prodi akuntansi yang ada di Bali.

2. Penelitian selanjutnya juga dapat menambahkan lagi variabel independen kecerdasan yang dapat mempengaruhi pemahaman akuntansi seperti halnya kecerdasan intelektual atau kecerdasan spiritual, selain kecerdasan emosional yang sudah digunakan dalam penelitian ini.

\section{DAFTAR PUSTAKA}

Budhiyanto, Suryanti J. \& Nugroho, Ika P. 2004. Pengaruh Kecerdasan Emosional terhadap Tingkat Pemahaman Akuntansi. Jurnal Ekonomi Bisnis, Vol. X, No.2. Hal.260281.

Budi, Cahyo Santoso dan Benny Rinaldi. 2018. Pengaruh Kecerdasan Emosional Dan Gaya Belajar Terhadap Pemahaman Akuntansi Dan Lingkungan Keluarga Sebagai Variabel Moderasi (Studi Kasus Pada Mahsiswa Akuntansi Universitas Riau Kepulauan Tahun Angakatan 2013-2016). Jurnal Akuntansi. Vol.12 No. 2: 14-25. 
Diabnita, Destu. 2014. Pengaruh Prilaku Belajar, Gaya Mengajar Dosen, Dan Kecerdasan Emosional Terhadap Pemahaman Mahasiswa Pada Mata Kuliah Pengantar Akuntansi. Skripsi. Fakultas Ekonomi Dan Bisnis.Bengkulu :Universitas Bengkulu.

Goleman, Daniel.

2003. Kepemimpinan Yang Mendatangkan Hasil, Cetakan Pertama, Amara Books, Jokjakarta.

Hidayah, Khikmatul. 2016. Pengaruh Kuliah Sambil Bekerja Dan Aktivitas Belajar Terhadap Prestasi Belajar Mahasiwa Angkatan 2011 Jurusan Pendidikan IPS UIN Maliki Malang. Skripsi, Fakultas Ilmu Tarbiyah Dan Keguruan.Malang:Universitas Islam Negeri Maulana Malik Ibrahim Malang.

Indriantoro, Nur, dan Bambang Supomo. 1999. Metodologi Penelitian dan Bisnis, Yogyakarta: BPFE Yogyakarta.

Matius, Manurung Dedi dan Hamidi. 2017. Pengaruh Latar Belakang Pendidikan dan Status Bekerja Mahaiswa Terhadap Pemahaman Akuntansi. Jurnal Akuntansi. Vol.11 No. 1: 1-10

Nurdin, Nazar. 2015. Kuliah Sambil Bekerja, Zuma Bisa Jadi Wisudawan Terbaik. Kompas.com (Online). (https://regional.kompas.com/r ead/2015/01/29/20305761/Kul iah.Sambil.Bekerja.Zuma.Bisa Jadi.Wisudawan.Terbaik. Diakses tanggal 10 Desember 2019).

Puteri, Sari Immu dan Reni Sartika. 2018. Pengaruh Prilaku Belajar, Gaya Mengajar Dosen Dan Kecerdasan Emosional Terhadap Pemahaman Mahasiswa Pada Mata Kuliah Pengantar Akuntansi. Jurnal Akuntansi .Volume IV No. 2 : 39-49.

Rachmi, Filia. 2010. Pengaruh Kecerdasaan Emosional, Kecerdasaan Spiritual dan Perilaku Belajar terhadap Tingkat Pemahaman Mahasiswa Akunatnsi. (Studi Empiris pada Mahasiswa Akuntansi Universitas di Ponegoro Semarang dan Universitas Gadja Mada Yogyakarta). Skripsi. Semarang: Fakultas Ekonomi Universitas Diponegoro Semarang.

Rohmah, Nelly. 2019. Pengaruh Kecerdasan Emosional, Prilaku Belajar, Dan Kompetensi Dosen Terhadap Pemahaman Akuntansi (Studi pada Mahasiswa Akuntansi Syariah Fakultas Ekonomi dan Bisnis Islam IAIN Surakarta). Skripsi, Fakultas Ekonomi Dan Bisnis Islam.Surakarta:Institut Agama Islam Negeri Surakarta.

Saputra, Komang Tri Wira. 2018. Pengaruh Kecerdasan 
Emosional, Kecerdasan

Spiritual, dan Kecerdasan

Intelektual Terhadap Tingkat

Pemahaman Akuntansi (Studi

Empiris pada Mahasiswa

Akuntansi Universitas Negeri

Yogyakarta). Skripsi.

Yogyakarta. Fakultas

Ekomoni: Universitas Negeri

Yogyakarta.

Soemanto, Wasty. 2012. Psikologi

Pendidikan. Jakarta: Rineka

Cipta

Sugiyono .2015. Metode Penelitian

Pendidikan (Pendekatan

Kuantitatif, Kualitatif dan

R\&D). Penerbit CV. Alfabeta:

Bandung.

Suwardjono . 2005. Teori Akuntansi:

Perekayasaan Pelaporan

Keuangan (Edisi III).

Yogyakarta: BPFE.

Yaumi, Muhammad. 2013. Prinsip-

Prinsip Desain Pembelajaran.

Jakarta: Fajar Interpratama

Mandiri.

Zakiah, Farah. 2013. Pengaruh Kecerdasan Intelektual, Kecerdasan Emosional dan Kecerdasan Spiritual Terhadap Pemahaman Akuntansi (Studi Empiris Mahasiswa Jurusan Akuntansi Angkatan Tahun 2009 di Universitas Jember). Skripsi, $\quad$ Fakultas Ekonomi.Jember.: Universitas Jember. 